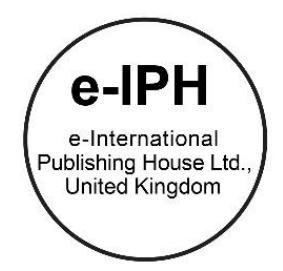

\title{
Socio-Demographic Influencing Behaviour against Solid Waste Minimisation in Shah Alam City, Malaysia
}

\author{
Nor Eeda Haji Ali1 ${ }^{1}$ Ho Chin Siong², Halmi Zainol'1 Nurain Mohd Talmizi \\ 'Department of Town and Regional Planning, Faculty of Architecture, Planning and Surveying, \\ Universiti Teknologi MARA, Seri Iskandar Campus, Perak Branch, 32610, Perak, Malaysia. \\ 2Department of Urban and Regional Planning, Faculty of Built Environment, \\ Universiti Teknologi Malaysia, Skudai, Johor, Malaysia. \\ noree038@perak.uitm.edu.my \\ Tel:6013 - 3087204
}

\begin{abstract}
Waste management is one of the most challenging problems. This study investigates the influence of household attributes on waste minimisation behaviour in Shah Alam City, Malaysia. Through a household survey, 300 respondents were randomly chosen. Findings from the study revealed that respondents behaviour has statistically significant associations with 4 socio-demographic, namely gender $[F(298)=7.33, p=0.00]$; race $[F(2,297)=$ $3.22, p=0.04]$; marital status $[F(2,297)=3.51, p=0.03]$; home ownership $[F(2,295)=7.57, p=0.00]$. The results of this analysis will facilitate the implementation of policies for sustainable solid waste minimisation.
\end{abstract}

Keywords: Solid waste management, Solid waste minimisation, Socio-demographic, Behaviour.

eISSN: 2398-4287C 2017. The Authors. Published for AMER ABRA by e-International Publishing House, Ltd., UK. This is an open access article under the CC BYNCND license (http://creativecommons.org/licenses/by-nc-nd/4.0/). Peer-review under responsibility of AMER (Association of Malaysian Environment-Behaviour Researchers), ABRA (Association of Behavioural Researchers on Asians) and cE-Bs (Centre for Environment-Behaviour Studies), Faculty of Architecture, Planning \& Surveying, Universiti Teknologi MARA, Malaysia.

https://doi.org/10.21834/e-bpj.v2i6.989

\subsection{Introduction}

The growth of an inadequate infrastructure, rapid developments in technology, world's population, increasing urbanisation are factors influence solid waste generation (SWG). Municipal waste management (MWM) is one of the most challenging problems and present a serious challenge to local authorities and planners in developing countries caused by the generated of large waste quantities. In Malaysia, the total quantity of municipal solid waste generated will increase from 19,100 tons of waste per day in 2005 to 30,000 tons per day by 2020 , if the annual rate population growth of 2.5 per cent. Furthermore, this rate is expected to increase significantly as the Malaysian economy grows in 2020; as such the Malaysian government needs to spend more towards achieving sustainable solid waste minimisation. Solid waste minimisation as an approach to solid waste management (SWM) helps in the separation of wastes from the source. Government's efforts to improve SWM and the involvement of households towards achieving a sustainable SWM is one major way of achieving a sustainable SWM, especially on 3Rs concept. In these issues, the stakeholders are working together to manage the SWM system properly. The main factors include the country's lack of an efficient institutional framework, the lack of regulation, such as policies and strategies to promote the $3 R s$, and the lack of infrastructure to encourage the use of recycling. Influence households socio-demographic on behaviour factors in solid waste minimisation are believed to achieving sustainable SWM on 3Rs concept. A study by Rousta (2008) noted that there is a need for such a system to be implemented within a society, training be given to show people how to separate their wastes, selection of the best technology for the treatment of wastes, and the control of environmental impact of waste. However, achieving this requires a complicated system. Given the above background, this study aims to identify ways to improve solid waste minimisation to help in the achievement of sustainable development or "A Better Quality of

eISSN: 2398-4287C 2017. The Authors. Published for AMER ABRA by e-International Publishing House, Ltd., UK. This is an open access article under the CC BYNCND license (http://creativecommons.org/licenses/by-nc-nd/4.0/). Peer-review under responsibility of AMER (Association of Malaysian Environment-Behaviour Researchers), ABRA (Association of Behavioural Researchers on Asians) and cE-Bs (Centre for Environment-Behaviour Studies), Faculty of Architecture, Planning \& Surveying, Universiti Teknologi MARA, Malaysia.

https://doi.org/10.21834/e-bpj.v2i6.989 
Life". The objectives of the study (i) to examine the influence of households socio-demographic characteristics on behaviour factors in solid waste minimisation; (ii) to examine those factors hindering effective solid waste minimisation of households behaviour in neighbourhood area. Although government has been making various efforts to improve MSW, the involvement of households towards achieving a sustainable SWM system could be said to be low in Malaysia. If this can be achieved successfully, it can save fuel and money and reduce environmental degradation.

\subsection{Solid Waste Management System}

SWM is defined as the control of waste generation, storage, collection, transfer and transport, processing and disposal consistent with the best practice taking into consideration public health, financial, legal and environmental implications. Solid waste minimisation is the process of reducing the amount in waste streams. The importance concept of waste minimisation is through 3Rs (Franchetti, 2009) and treatment (Schall, 1992). Solid waste minimisation hierarchy incorporates the concept of reducing solid waste in stream. The process involves six steps ranked according to environmental impact. Reducing, which offers the best outcomes from 3Rs concept for the environment and the top of the priority order, followed by treatment concept (composting and incineration) and disposal. Treatment concept, which is in turn better than disposal to landfill. Figure 1 shown that the reduction is the most preferred option while the landfill is seen as the least favored option.

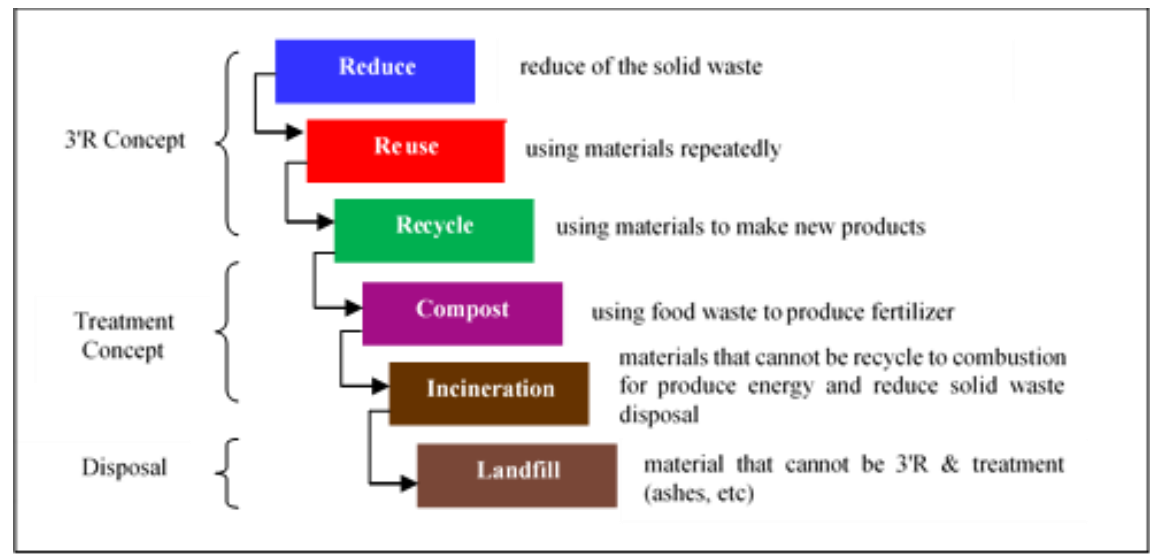

Fig 1. Pyramid of Solid Waste Minimisation

(Sources: Compiled from Franchetti, (2009); Schall, (1992)

Waste reduction is first in the hierarchy of SWM and is a difficult alternative compared to recycling. In the housing area, households must reduce the amount of municipal solid waste being produced. They need to imbibe such attitude like bringing their own bags to shopping, using the tool replenishment of buying new containers and others that can reduce the waste from waste stream (Worrell \& Vesilind, 2012). Reuse items means that materials are still useful and have utility or value for more than one purpose instead of throwing them away. Households can reuse or give them to others who need it, rather than throw away in waste stream (Worrell \& Vesilind, 2012). Recycling is the process of separating out the waste materials that are useable for recycling so that they can be collected separately from the rest of the solid waste. The recycling materials are glass, plastic, paper, cardboard, and others that are used for the manufacture of new products (Worrell \& Vesilind, 2012). Treatment is the last option for reducing solid waste from waste stream. Composting is one of the treatment concepts for reduction technique that can divert large volumes. Composting only focuses on food and home waste. Incineration can be defined as a process of controlled combustion for burning solid waste. In this process, carbon, hydrogen and other elements in the waste are combined with oxygen in the combustion air which generates heat.

\subsection{Socio-demographic Characteristics and Psychological Factors}

In previous studies Ebreo and Vining (2001); Mutangga and Haron (2012) asserted the existence of related values within the sociodemographic characteristics and psychological factors (knowledge and behaviour) that affect participation in waste minimisation. The purpose is to understand and to focus on the categories of household based on the socio-demographic factors that can encourage environmentally responsible behaviour in the residential sector. Knowledge about the impact of waste recycling on the environment has a positive relationship to recycling practice/attitude and behaviour (Makmattayan, 2003). Generally, the more knowledge about waste minimisation and its impact on the natural world, the more likely it is that a household will practise it (Schultz et al., 1995). Oskamp et al., (1991) noted that behaviour may also be reduced because of lack knowledge about waste minimisation and environmental issues. People who show greater knowledge and concerns about the recycling and environment have higher levels of participation in waste minimisation (De, 1989; Vining and Ebreo, 1990; Gamba and Oskamp, 1994; Diamantoplous et al., 2003; Seunghae and Paik, 2011). 


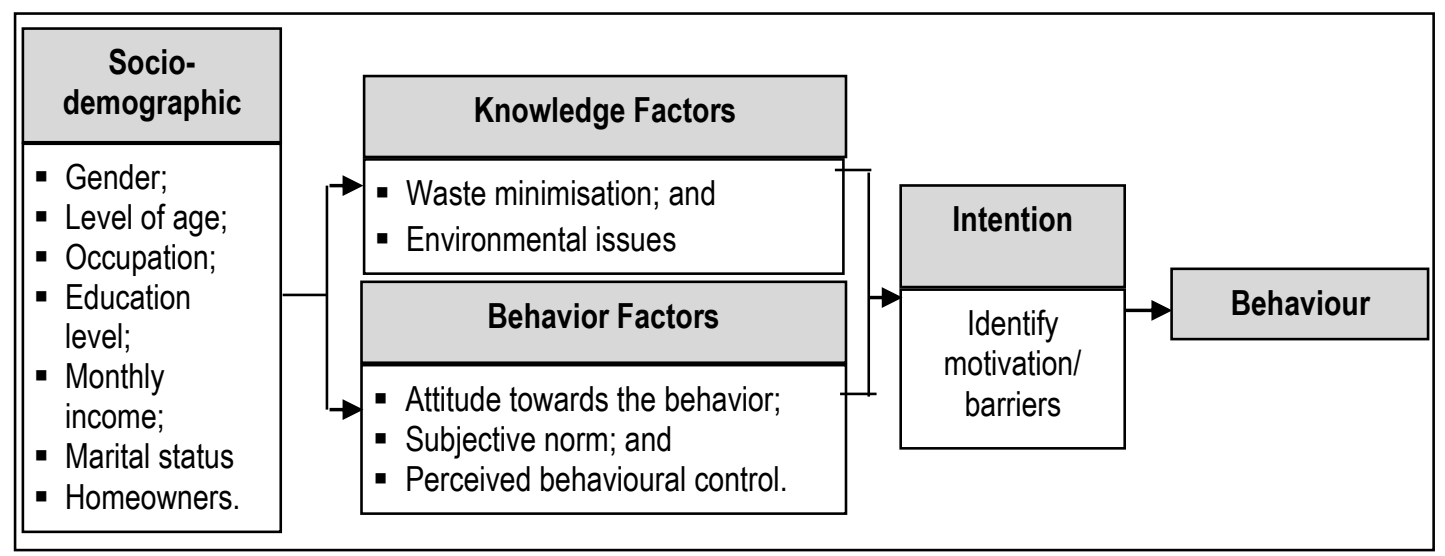

Fig 2. Connecting links between people's knowledge and attitude and their behavior (Sources: Compiled from Makmattayan (2003); Schultz et al., (1995); Ajzen (1991)

Socio-demographic and psychological factors have been found to play a significant part in shaping solid waste minimisation. This study focuses on the psychological factors of behaviours regarding solid waste minimisation. Solid waste minimisation as an approach to SWM helps in the separation of wastes from the source.

\subsection{Factors Influencing of Household Solid Waste Management System}

The study has identified several factors that influence the use of a household SWM system. Indeed, six factors are frequently cited which influence the use of household SWM systems in either developed or developing countries, as illustrated in Figure 3.

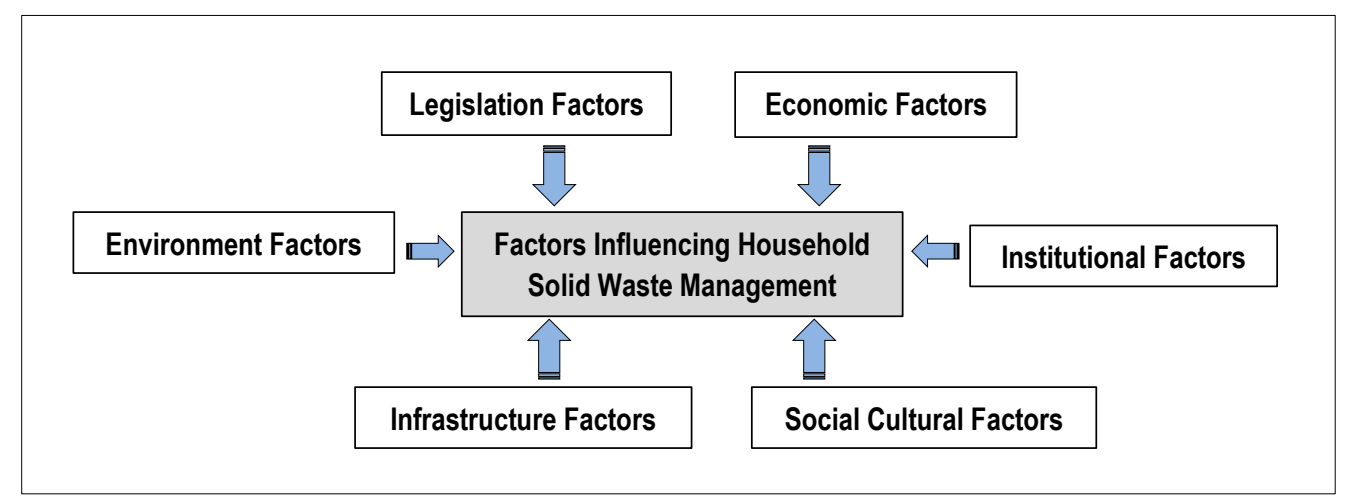

Fig 3. Six factors influencing the use of household SWM systems

(Sources: N.E Haji Ali, 2017)

According to Thorneloe et al. (2002), SWM systems produce $4 \%$ of all anthropogenic GHG emissions and landfills contribute $90 \%$ of the largest anthropogenic GHG emissions. In addition to $\mathrm{GHG}$ emissions, the resulting leachate can also lead to polluted water and can have serious ramifications for all living creatures, including humans, and for the ecosystem (McMichael, 2000). Knowledge and public awareness are important factors to ensure that people know the objectives, strengths, and weaknesses of the strategy. The success of solid waste minimisation is influenced by people's attitudes and patterns of waste handling. Households will be involved in waste recycling when they have the knowledge about the importance and impact of such practices. If there is a lack of knowledge about solid waste minimisation among households, then they cannot be considered to have any responsibility for recycling (Goldon and Yang, 1995; Ezeah et al., 2009). If there is a lack of available financing for the promotion of waste minimisation, households may have little or no awareness of the existing problems of waste (Gordon and Yang, 1995). The lack of legislation on SWM systems has also been cited as being partially responsible for the undefined roles of agencies in the waste sector as well for as the lack of coordination among them (Joseph, 2006). The legislative and policy framework in solid waste management system is weak and lacks clear strategies for action (Ezeah and Robert, 2012). However, the law can promote or prevent any SWM policies. However, with four years to go before the target date of 2020 , how is this goal of $22 \%$ waste minimisation feasible in Malaysia? Therefore, a comprehensive study needs to be carried out the influence of households socio-demographic characteristics on behaviour factors in solid waste minimisation; and to examine those factors hindering effective solid waste minimisation of households behaviour in neighbourhood area is important, as it would help policy makers, the government, local authorities, and urban planners to facilitate the design of environmental policies, strategies, and programs in the future. 


\subsection{Methodology}

To achieve the objective of examining socio-demographic characteristics that influence household waste minimisation in residential areas, this survey had to be conducted among all three types of housing (low cost, medium cost, high cost). The household survey was conducted in section 7, Shah Alam city, Selangor, Malaysia. Stratified sample technique was used in selection of respondents that participated in the survey. The questionnaires were administered personally to ensure a speedy and sizable response to the questions and to offer explanations to the households on some of the concepts used in the questionnaire even though the structuring, phrasing, and working of the questionnaires were made as simple as possible to take into account that recycling is almost a new concept to many households. The questionnaire was distributed to a sample of 500 households, but not all cooperated. The researcher aimed to obtain a minimum of 300 responses and finally succeeded. To achieve the first objectives, the questionnaire comprises of two sections. Section A contains the demographic information of respondents while section B focused on questions relating to behavior towards waste minimisation. The questions in section $B$ were measured on three-point Likert scale ranging from 1 $=$ Never, 2 = Sometimes, 3 = Always. While the second objectives, add of Section $C$ contains the action, opinion and recommendations of respondents on solid waste minimisation. The questionnaire was designed in both English language and Bahasa language in order to give those respondents who may not understand English language the opportunity to participate. Data was analysed using the SPSS version 20. Analysis of one-way ANOVA was conducted to determine whether or not differences exist in groups means of some selected household attributes with espect to the items used to capture behavior on waste minimisation.

\subsection{Analysis \& Findings}

The analysis focuses on the inter-relationships between the socio-demographic characteristics and the respondents behavior on solid waste minimisation. Out of the two demographic variables analysed using t-tests, significant differences can be seen to exist between males and females in relation to several of the specific environmental behaviours described above. Value of $(F=7.328, p=0.00)$ were recorded, which is less than the p-value threshold of 0.05 . In comparison with men, which recorded a value of (1.8802), females recorded a higher a value of (1.9424); therefore, women show a significantly greater behaviour towards solid waste minimisation (see Table 1). It is also revealed that female respondents demonstrated stronger behaviours than male respondents in terms of separation for solid waste minimisation. For instance, Murad and Siwar (2007) reported that women had stronger behaviours and attitudes than men towards solid waste minimisation. Nonetheless, these findings contradict the study conducted by Tonglet et al., (2004).

Table 1. Behaviour towards solid waste minimisation by gender

\begin{tabular}{lll}
\hline Gender & Mean & Std. Deviation \\
\hline Male & 1.8802 & .47314 \\
Female & 1.9424 & .38819 \\
\hline & $\mathrm{F}=7.328, \quad$ (d) $298, \quad \mathrm{p}=0.00, \quad \mathrm{t}=.223$
\end{tabular}

(Source: N.E Haji Ali, 2017)

The study found that the age of the respondents had no significant effect on practice regarding household waste management. Value of $(F=2.106, p=0.08)$ were recorded, which is more than the $p$-value threshold of 0.05 . This is contrary to the study by Van Liere and Dunlap (1980), who stated that it is easier for younger people to be involved with activities related to solid waste minimisation. The results in Figure 3 show significant differences between level of behaviour on solid waste minimisation and race categories, with value of $(F=3.217, p=0.04)$ being recorded, which is less than the $p$-value threshold of 0.05 . The test shows that Indians recorded (2.0167) the highest level of participation. The Chinese were next (1.9444) and the Malays showed the least (1.8593).

$F=3.217, \quad$ (d) $2, \quad p=0.04$

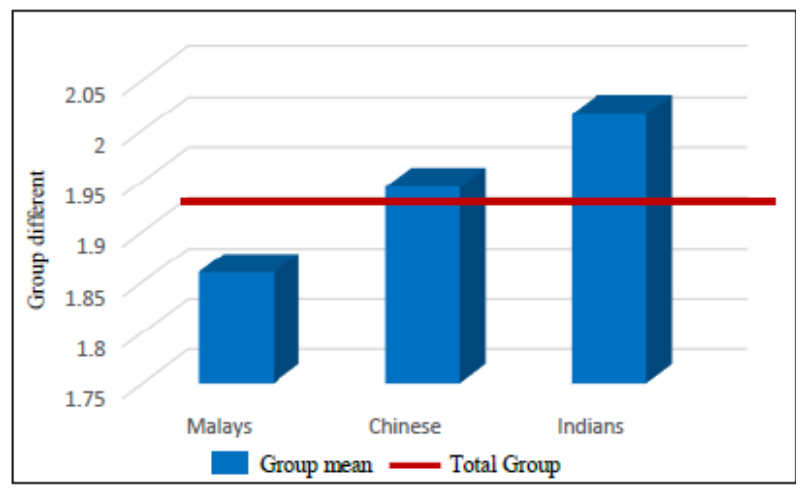

Fig 3. Behaviour on solid waste minimisation by race (Source: N.E Haji Ali, 2017) 
This section considers the respondents behaviour on solid waste minimisation based on their marital status. The study found a high level of significance $(F=3.510, p=0.03)$ between marital status and behaviour towards solid waste minimisation. The outcome showed that the married respondents (1.9488) tended to perform better than the single respondents (not maried) (1.7965) on solid waste minimisation (see Figure 4), and married households undertook higher levels of green/recycling behavior than those who were single. This aligns with the findings of Medina et al. (2006) and Tonglet et al. (2004).

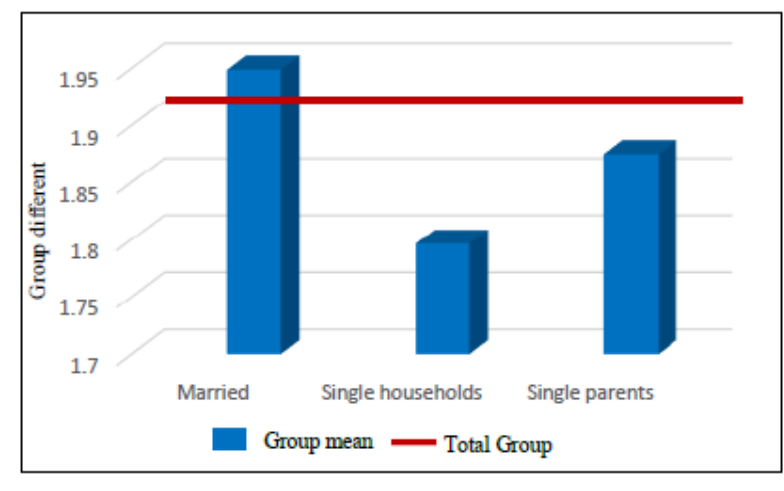

$F=3.510, \quad$ (d) $2, \quad p=0.03$

Fig 4. Behaviour towards solid waste minimisation by marriage status (Source: N.E Haji Ali, 2017)

The study also found that there was no significant relationship between occupation and behaviour towards solid waste minimisation, with value of $(F=0.991, p=0.43)$ being recorded, which is more than the $p$-value threshold of 0.05 . Each mean value is nearly equal to each type of occupations values: professional (1.9213), semi-professional (1.9825), labourer (1.8750), self-employed (1.9141), homemaker (1.9487), not working (1.8333) and others (1.7752). This finding is in contrast to the study conducted by Tsai (2008), who found that retirees showed more initiative to reduce the quantity of solid waste than did others. The result shows no significant relationship between educational level and behaviour towards solid waste minimisation. Value of $(F=2.184, p=0.09)$ were recorded, which is more than the $p$-value threshold of 0.05 . No significant difference among the mean value for the groups, with value recorded as follows: postgraduate (2.0580), school graduate (1.9510), certificate and diploma (1.9454), and degree (1.8491). This finding supported the findings of research by Makmattayan (2003), Seunghae and Paik (2011), Murad and Siwar (2007). However, findings from Barr et al. (2003) showed that there is a significant relationship, which is relatively homogeneous. The better educated tend to demonstrate more behaviours regarding solid waste minimisation. However, despite a better understanding of the issues, households still do not participate in solid waste minimisation. In this regard, there was no relationship between household monthly income and behaviour towards solid waste minimisation, with a value of $(F=1.947, p=0.12)$ being recorded, which is more than the $p$-value threshold of 0.05 . This negative outcome shows that there is no relationship between household monthly income and participation in solid waste minimisation. This finding is contrary to Makmattayan (2003), who asserted that differences in income could create different levels of attitude and behaviour in that people who are earning more are more likely to recycle than people who are earning less (Tsai, 2008; Ohakwe et al., 2011).

The study found that there is no significant difference between categories of housing and behaviour regarding solid waste minimisation, with value of $(F=2.139, p=0.12)$ being recorded, which is more than the $p$-value threshold of 0.05 . The results, which seem to indicate that all categories of housing share similar knowledge on the subject matter. The results include high cost (1.9600), medium cost (1.9267) and low cost (1.8367) housing. In the case of home ownership and behaviour, the study found a relationship between home ownership and behaviour regarding solid waste minimisation with output value of $(F=7.568, p=0.00)$ being recorded, which is less than the $p$-value threshold of 0.05 . Home ownership recorded (1.9959), thereby indicating that home owners demonstrate solid waste minimisation behaviour than do rental households, who recorded (1.8010) (see Table 2). This is similar to previous studies that homeowners show greater behaviour regarding solid waste minimisation than do rental households (Tonglet et al., 2004; Nixon and Saphores, 2009; and Medina et al., 2006).

Table 2. Behaviour towards solid waste minimisation by home ownership

\begin{tabular}{lrl}
\hline Home owner & Mean & Std. Deviation \\
\hline Own & 1.9959 & .41498 \\
Rent & 1.8010 & .44800 \\
Others & 1.9333 & .27889 \\
\hline & F=7.568, (d) 2, $\quad$ p=0.00 & \\
& (Source: N.E Haji Ali, 2017)
\end{tabular}

The analysis also revealed that the difference between the mean for the females is $(\mu=1.9424)$ and the mean for the males is $(\mu=1.8802)$ gave a value of 0.0622 . In this case showed that the females had more behavioural tendencies on solid waste minimisation than the males. The mean result for home ownership is $(\mu=1.9959)$ is higher than the mean for tenants $(\mu=1.8010)$ by 
0.1949 and so indicates that homeowners have more behavioural consciousness about solid waste minimisation. Furthermore, while examining the variable of marital status, it was found that the mean for the married households is $(\mu=1.9488)$ was greater than the mean for the single households $(\mu=1.7965)$, by 0.1523 , which indicates that such households have more behavioural tendencies to practise solid waste minimisation than single households. The study also found that the mean for the Indian households $(\mu=2.0167)$ indicated that they tended to have more behavioural consciousness than the mean for the Chinese is $(\mu=1.9444)$ and the mean for Malay households $(\mu=1.8593)$ households on solid waste minimisation (refer Figure 6).

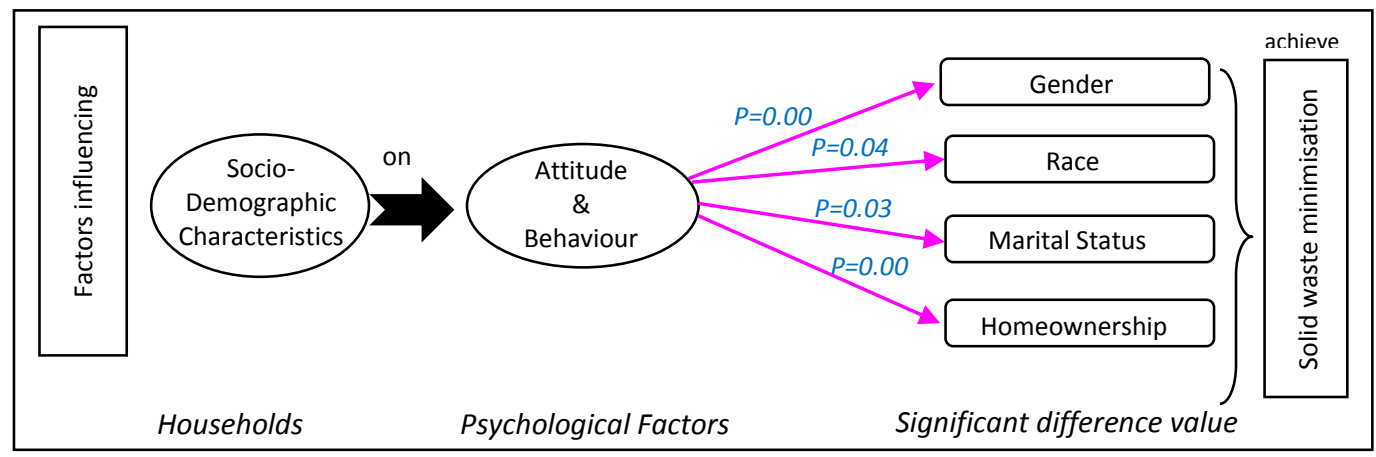

Fig 5. Factors influencing socio-demographic characteristics on behaviour towards increase solid waste minimisation (Source: N.E Haji Ali, 2017)

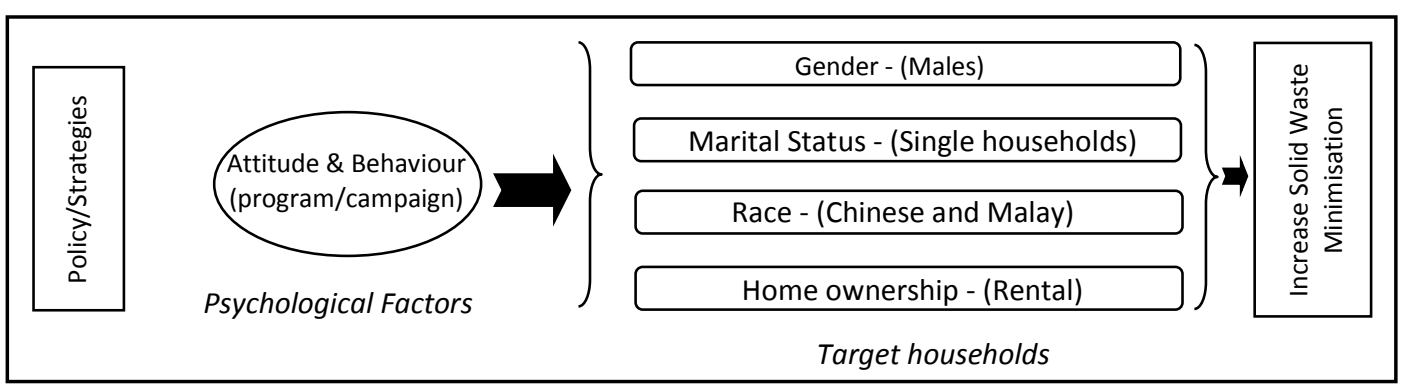

Fig 6. Target households for policy makers to increase solid waste minimisation (Source: N.E Haji Ali, 2017)

To achieve this objective, it is crucial to assist the relevant parties to increase the level of participation or to engage with the public on solid waste minimisation. What are the policy implications of these significant differences? How relevant policy maker when designing policy instruments to achieve the research objectives number one in this study? Ebreo and Vining (2001) explained that relevant socio-demographic characteristics can influence behaviour regarding solid waste minimisation among households, and they can also be a significant determinant in the environment related to solid waste minimisation. The socio-demographic significant differences in behaviour suggest that campaigns/programs to raise awareness of how to participate in recycling should be concentrated on the Malays and the Chinese, on rental households, and on male and unmarried persons.

Why respondents did practice solid waste minimisation? Does the local authority assist in improving solid waste minimisation? Results from Table 3 shown that about $42 \%$ of the respondents agreed that the local authority has been creating awareness on waste minimisation among households in the neighbourhood area, though 30\% stated otherwise, and $28 \%$ of respondents do not know whether the local authority have done something or not. What this implies is that most households were either unaware of the waste minimisation activities of the local authority or do not believe they are doing much in terms of promoting, carrying, providing towards waste minimisation.

Table 3: Involvement of local authority in waste minimisation

\begin{tabular}{llcc}
\hline & \multicolumn{2}{c}{ Promotion and carrying out waste minimisation in the neighbourhood } & \multirow{2}{*}{$\%$} \\
\cline { 2 - 4 } & & Evaluation & $\%$ \\
\hline Yes & Very poor & 21.00 & 42.00 \\
& Poor & 11.00 & \\
& Good & 10.00 & 30.00 \\
\hline & Excellent & 00.00 & 28.00 \\
\hline No & & & 100.00 \\
\hline Do not know & &
\end{tabular}


Results in Table 4 shown that more than half (64\%) of the respondents stated that the facilities provided in neighbourhood area for waste minimisation by the local authority was inadequate, while only a handful $(36 \%)$ stated it was adequate. When further asked, what the facilities or services were lacking in their neighbourhood area, they maintained that the facilities like recycle bins have spoilt and since that time it has not been replaced (54\%). The respondents also need a schedule for collection and the strategic location places of collection points in the neighbourhood so that community will have access to the recycling bins provided.

Table 4: Provision of Facilities by local authority

\begin{tabular}{|c|c|c|c|}
\hline \multirow{2}{*}{ Provision of Facilities by local authority } & Yes & No & Total \\
\hline & $\%$ & $\%$ & $\%$ \\
\hline \multicolumn{4}{|l|}{ Are the facilities provided for waste minimisation by the Local Authority in your residential area adequate? } \\
\hline \multicolumn{4}{|l|}{ If NO, what facilities or services are lacking in your residential area? } \\
\hline $\begin{array}{l}\text { More recycling bin, many current recycling bins have spoilt and last time have recycling bin but now don't have } \\
\text { (only have notice board) }\end{array}$ & & 54.00 & 64.00 \\
\hline Must have schedule for collection & & 43.00 & \\
\hline Must have strategic location so that it is easy to see and handle & & 03.00 & \\
\hline
\end{tabular}

(Source : N.E Haji Ali, 2017)

Results in Table 5 shown that $47 \%$ of the respondents stated that lack of promoting awareness from local authority has hindered waste recycling or waste minimisation. A total of $34 \%$ maintained that lack of recycling facilities is one of the major factors impeding on waste minimisation. Other factors given by the respondents are vandalism of waste minimisation facilities, cost, political will of government, and non-location of collection points at strategic places were identified as factors hindering towards waste minimisation in case study. When further asked on what should be done by local authority to improve on waste recycling or waste minimisation, they stressed the need for corporation by all stakeholders involved in every stages especially in management of solid waste minimisation. Other suggestions, they want the creation of separation points for organic and in-organic wastes especially on each houses.

Table 5: The factors hindering towards waste minimisation

\begin{tabular}{|c|c|}
\hline Factors & $\%$ \\
\hline Lack of publicity/awareness & 47.00 \\
\hline Lack of recycling facilities & 34.00 \\
\hline Vandalism & 06.00 \\
\hline Political will of government & 05.00 \\
\hline Non-strategic location of facilities & 05.00 \\
\hline Cost & 03.00 \\
\hline Total & 100.00 \\
\hline
\end{tabular}

When asked, what needs to be done either individually or government to improve waste minimisation? The results shown that $44 \%$ of the respondents suggested more enlightenment or promotion campaign by the local authority on waste minimisation and the campaign must focus on each types of housing. This shown that the respondents ready or willing to participate in solid waste minimisation, assisted by the government. Other factors given $28 \%$ respondents, needs the creation or provide of more recycle bins. In addition, a total of $9 \%$ suggested the adoption a schedule for waste collection and $8 \%$ advocated the need for separation of the organic wastes before the waste contractor collect to their final disposal. Other suggestion includes: cooperation of various stakeholders involved in waste management and taking a cue from other countries that have successfully implemented waste minimisation.

Table 6: Suggestions for improve solid waste minimisation

\begin{tabular}{lc}
\hline \multicolumn{1}{c}{ Suggestions/Commends } & $\%$ \\
\hline Creation or campaign of awareness towards waste minimisation & 44.00 \\
Create more recycling bins & 28.00 \\
Adoption a schedule for solid waste collection & 09.00 \\
Separation of organic and inorganic wastes for collection points & 08.00 \\
Learn from the best country practice on waste minimisation & 07.00 \\
Fine defaulters who are found throwing recyclable materials & 06.00 \\
Corporation of all stakeholders & 05.00 \\
\hline \multicolumn{2}{c}{ Total } \\
\hline (Source: N.E Haji Ali, 2017)
\end{tabular}

This finding also brings new insights to policy makers in facilitating the design of environmental policies, strategies, and programs with the objective of increasing behaviour towards solid waste minimisation. As discussed earlier, it is necessary to understand how the socio-demographic characteristics influence the behaviour of households regarding solid waste minimisation to enable policy, strategy, and program makers to take decisions about the target groups (specific groups) as well as where and when to implement a policy. 


\subsection{Conclusion}

Waste minimisation as an approach to solid waste management helps in the separation of wastes from the source. Government have initiated various programmes on solid waste minimisation such as, Street, drainage and building Act 1974, Solid waste and public cleansing Act 2007. However, the success of these programmes to a certain level lies on the corporation of households. To this end, households are expected to key in to such initiatives by government towards sustainable waste management. This study looks at the households behavior towards waste minimisation in Shah Alam city, Selangor. Findings show that the behaviour of households in the study area on waste minimization is above average, which suggests that they are aware of the concept of waste minimisation. However, the results also revealed four significant differences within the socio-demographic characteristics with respect to behaviour regarding solid waste minimisation. These significant difference found in the analysis include gender $(p=0.00)$, race $(p=0.04)$, marital status $(p=0.03)$, and home ownership $(p=0.00)$, with $p$-values less than the 0.05 threshold. Understanding and changing behaviours is complex, and economics (including behavioural economics) and social research can contribute to developing policies that take into account this complexity and so achieve successful changes in behaviours. For a developing country like Malaysia, the involvement of households in its solid waste management programme is necessary in order to achieve the desired results. In this regard, the local authorities and other stakeholders should embark on massive enlightenment campaign to sensitive the citizens on the need to engage in waste minimisation. Recommendations for improving the situation focus on behavioural change by households. These changes will enable households to improve their attitude and behavior and traditions towards recycling. The solid waste minimisation can be increased through various strategies; i) Public education to enhance environmental awareness; ii) Promotion of waste minimisation (4Rs) at the source of generation; iii) Separation of Waste at the Source of Generation. This will bring new insights to policy makers in facilitating the design of environmental policies, strategies, and programs with the objective of changing individual behaviour towards solid waste minimisation. Socio-demographic variables may be important factors that make it possible to target policy instruments at specific groups. However, targeting measures may entail important administrative costs that need to be taken into account by policy makers. This is more significant than targeting policies to demonstrate good behaviour towards solid waste minimisation.

\subsection{Acknowledgements}

Appreciation to Universiti Teknologi MARA in collaboration with the Malaysian Ministry of Education to funded this study to be successfully completed.

\subsection{References}

Agamuthu, P. and Hamid, F.S. (2007). Recent Issues in Solid Waste Management in Malaysia: The Solid Waste Bill, Journal of Material Cycles Waste Management, 11, 96-103.

Ahorlu, W. K. (2006). Managing Waste in Africa - A Look at Institutional Constraints, Hazardous Waste and Public-Private Partnership Options. Retrieved on February 11, 2012, from http://www.unitar.org.

Ajzen, I. (1991). The Theory of Planned Behaviour, Journal of Organisational Behaviour and Human Decision Processes, 50(2), 179-211.

Barr, S., Ford, N.J. and Gilg, A.W. (2003). Attitudes towards Recycling Household Waste in Exeter, Devon: Quantitative and Qualitative Approaches, Journal of Local Environment, 8(4), 407-421.

Bishop, K., \& Said, I., (2017). Looking Up for Waste Management \& Recycling, Exclusive North American sales and service for Bollegraaf, Lubo and TOMRA.

De Young, R. (1989). Exploring the differences between recyclers and non-recyclers: the role of information. Journal of Environmental Systems 18, 341-350.;

Diamantopoulos, A., Bodo, B. Schlegelmilch, Rudolf, R., Sinkovics and Greg, M.B. (2003). Can Socio-Demographics Still Play a Role in Profiling Green Consumers? A Review of the Evidence and an Empirical Investigation, Journal of Business Research, 56(6), 465-80.

EASUR (Urban Development Sector Unit East Asia and Pacific Region) (1999). What a Waste: Solid Waste Management in Asia and Pacific Region. United States of America: World Bank.

Ebreo, A. and Vining J. (2001). How Similar are Recycling and Waste Reduction? Future Orientation and Reasons for Reducing Waste as Predictors of Self-Reported Behaviour. Journal of Environment and Behaviour, 33, 424-48.

Evison, T. and Read, A.D. (2001). Local Authority Recycling and Waste Awareness Publicity/ Promotion, Journal of Resource Conservation Recycling, 32, $275-292$.

Ezeah, C., Roberts, C.L., Watkin, G.D, Philips, P.S. and Odunfa, A. (2009). Analysis of Barriers Affecting the Adoption on a Sustainable Municipal Solid Waste Management System in Nigeria. In the Proceedings of the 24th International Conference on Solid Waste Technology and Management, March 12-15, 2009. Widener University, Philadelphia, USA.

Ezeah, C. and Roberts, C.L. (2012). Analysis of Barriers and Success Factors Affecting the Adoption of Sustainable Management of Municipal Solid Waste in Nigeria. Journal of Environmental Management, 103, 9-14.

Ezeah, C., Jak, A., Fazakerley, L. and Clive, L.R. (2013). Emerging Trends in Informal Sector Recycling in Developing and Transition Countries, Journal of Waste Management, 33, 2509-2519. 
Franchetti MJ (2009) Solid Waste Analysis and Minimisation a systems approach. The McGraw-Franchetti Hill Companies, Inc, New York

Gamba, R.J. and Oskamp, S. (1994). Factors Influencing Community Residents Participation in Commingled Curbside Recycling Programs. Journal of Environment and Behavior, 26, 587-612.

Gordon, C. and Yang, C. (1995). Urban Waste Recycling in Taiwan, Resources, Journal of Conservation and Recycling, 13, 15-26.

Joseph, K. (2006). Stakeholder Participation in Municipal Solid Waste Management, Journal of Habitat International, 30, 863-871.

Kojima, M. and Rebullida, M.L.G. (2008). Stakeholders Relationships in Recycling Systems: Experiences in the Philippines and Japan. Retrieved on March 05, 2014, from http://d-arch.ide.go.jp.

Maldonado, L. (2006). Reduction and Recycling of Urban Waste at Higher Education Institutions: A Case Study, Revista Ingeniería, 10(1), 59-68.

Makmattayan, R. (2003). Factors Related to Solid Waste Sorting Behaviour among Housewives in Bang Sue District, Bangkok, Master's Thesis, Mahidol University.

McMichael, 2000 Mc. Michael, L. (2000). The Urban Environment and Health in a World of Increasing Globalisation, Bull World Health Org, 2000.

Medina, M., Williams, I.D. and Clark, M. (2006). Social, Cultural and Structural Influences on Household Waste Recycling: A Case Study, Journal of Resources, Conservation and Recycling, 48, 357-395.

Murad, M.W. and Siwar, C. (2007). Knowledge, Attitude and Behaviour of the Urban Poor Concerning Solid Waste Management: A Case Study, Journal of Applied Sciences, 7(22), 3356-3367.

Mutangga, J.A. and Haron, S.A. (2012). Factors Predicting Recycling Behaviour among Malaysian, Southeast Asia Psychology Journal, 1, 68-80.

Nixon, H. and Saphores, J.M. (2009). Information and the Decision to Recycle: Results from A Survey Of US Households, Journal of Environment Planning Management, 52, 257-277.

Nor Eeda Haji Ali (2017). Integrated Sustainable Household Solid Waste Management Using Solid Waste Minimisation Approach In Shah Alam, Selangor, Doctor of Philosophy Thesis, University. Technology Malaysia.

Ohakwe, J., Nnorom, I. and Iwueze, I. (2011). Survey of attitude of residents towards environmental deterioration in Nigeria and factors influencing their willingness to participate in reducing the trend: A case study of waste management. Journal of Applied Sciences Research, 6(2), 154-164.

Oskamp, S., Harrington, M.J, Edwards, T.C, Sherwood, D.L, Okuda, S.M. and Swanson, D.C. (1991). Factors Influencing Household Recycling Behaviour. Journal of Environment and Behaviour, 23(4), 494-519.

Rousta, K. (2008). Municipality Solid Waste Management An evaluation on the Borås System. Master. University Collage of Boras, Sweden.

Saeed, M.O., Hassan, M.N. and Mujeebu, M.A. (2009). Assessment of Municipal Solid Waste Generation and Recyclable Materials. Journal of Waste Management, 29 , 2209-2213.

Schall, J. (1992) Does the solid waste management hierarchy make sense? Working paper series, Programme on Solid Waste Policy, School of Forestry and Environmental Studies, Yale University.

Schultz, P.W., Oskamp, S. and Mainieri, T. (1995). Who Recycles and When? A Review of Personal and Situational Factors, Journal of Environmental Psychology, 15, 105-121.

Seunghae, L. and Paik, S.E. (2011). Korean Household Waste Management and Recycling Behaviour. Journal of Building and Environment, 46, 1159-1166.

Thorneloe, S., Weitz, K., Nishtala, S., Yarkosky, S. and Zannes, M. (2002). The Impact of Municipal Solid Waste Management on Greenhouse Gas Emissions in the United States. Journal of the Air and Waste Management Association, 52, 1000-1011.

Tonglet, M., Phillips, P.S. and Read, A.D. (2004). Using the Theory of Planned Behavior to Investigate the Determinants of Recycling Behaviour: a case Study from Brixworth, UK. Journal of Resources, Conservation and Recycling, 41, 191-214.

Tsai, T.H. (2008). The Impact of Social Capital on Regional Waste Recycling. Journal of Sustainable Development, 16, 44-55

Van Liere, K.D. and Dunlap, R.E. (1980). The Social Bases of Environmental Concern: A Review of Hypotheses, Explanations and Empirical Evidence. Journal of Public Opinion Quarterly, 44, 181-197.

Vining, J. and Ebreo, A. (1990). What Makes a Recycler? A Comparison of Recyclers and Non-recyclers, Journal of Environment and Behaviour, 22(1), 55-73.

William A. Worrell \& P. Aarne Vesilind, (2012), Second Edition : Solid Waste Engineering, United States of America.

Chang, N.-B., Y. C. Yang, and S. F. Wang. (1995). Solid waste management system analysis with noise control and traffic congestion limitations. Journal of Environmental Engineering, ASCE (in press).

Zhang, D.Q., Tan, S.K. and Gersberg, R.M. (2010). Municipal solid waste management in China: Status, Problems and Challenges. Journal of Environmental Management, 91(8), 32-45. 